\title{
EFEKTIVITAS PEMBELAJARAN BERBASIS DARING DALAM PANDANGAN SISWA
}

\author{
Irma Safitri ${ }^{1}$ \\ Program studi pendidikan guru madrasah ibtidaiyah Fakultas IImu Tarbiyah dan Keguruan Universitas Islam \\ Negri Syarif Hidayatullah Jakarta \\ Email :sftrirma1409@gmail.com
}

\begin{abstract}
Abstrak
Tujuan penelitian ini adalah untuk melakukan efektivitas pembelajaran dengan menggunakan online atau daring. Subjek pada jurnal adalah penelitian serta web yang membahas pembelajaran berbasis daring. Ruang lingkup dalam jurnal ini meliputi guru sekolah dan anak-anak sekolah dasar, serta peran dalam pemerintahan dalam mengupayakan pembelajaran berbasis daring saat ini.

Perkembangan pendidikan ini sangat berpengaruh dengan adanya pesat nya kesuksesan suatu informasi dengan komunikasi yang baik. Dan teknologi yang berperan dalam lingkungan saat ini dan pendidikan pun menggunakan untuk pembelajaran daring, pembelajaran daring ini bermanfaat untuk informasi dan komunikasi antara penghubung siswa dengan internet yang biasanya dilakukan selamanya. Media daring ini menggunakan subjek penelitian dengan berbagai macam-macam seperti whatshapp,google classroom,Edmodo, dan website lain nya. Metode yang kita gunakan dalam pengumpulan data melalui siswa-siswa dengan tanya jawab melalui aplikasi whatshapp.
\end{abstract}

Kata kunci: Efektivitas, Daring ,Siswa.

\section{PENDAHULUAN}

a. Latar Belakang Masalah

Pembelajaran daring merupakan salah satu cara menanggulangi masalah pendidikan tentang penyelenggaraan pembelajaran yang terjadi terkait dengan Coronavirus. Coronavirus merupakan penyakit mulai dari gejala ringan sampai berat. Masa inkubasi rata-rata 6-7 hari dengan masa inkubasi terpanjang 21 hari. Kemendikbud telah menyediakan waktu bagi sekolah untuk memilih platform belaja dirumah untuk mengeluarkan adanya proses berbagi pengetahuan, Kemendikbud menyediakan platform belajar daring gratis bernama "Rumah Belajar. Pembelajaran ini juga merupakan inovasi pendidikan untuk menjawab tantangan akan ketersediaan sumber belajar yang variatif. Selama pembelajaran daring, siswa kurang aktif dan kurang ikut serta selama pembelajaran berlangsung. Hal ini terjadi karena selama pembelajran daring, siswa banyak memiliki kendala, seperti kendala kurangnya alat bantu dalam pembelajaran seperti handphone, terbatasnya kemampuan siswa dalam mengoperasikan yang berhubungan dengan aplikasi online, kurangnya arahan dan dukungan dari orangtua tentang pentingnya pembelajaran daring di masa pandemi ini".

Pembelajaran secara daring kurang efektif terhadap hasil belajar siswa. Maka di perlukan adanya kegiatan blended learning untuk menghilangkan semua siswa dalam pemakaian komputer dan handphone pribadi untuk hal negatif. Kita juga bisa menggunakan metode Edmodo ialah pengajaran dengan jaringan sosial yang aman praktis dalam membantu guru untuk mengelola kelas virtual berdasarkan pembagian kelas nyata di sekolah, 
b. Deskripsi teori

1. Efektivitas

Adalah jangkauan usaha bidang untuk suatu jaringan dengan aktivitas daya tertentu untuk mendapatkan hal yang ingin dituju tanpa menghilangkan langkah dan sumber daya itu serta tanpa menghasilkan efek yang tidak harusnya ada dalam pelaksanaannya. Pemakaian model belajar bisa diaturkan dengan konsep yang dibahas hingga keinginan untuk berapa hal dan semua komponen digunakan dengan tepat.

Pembelajaran model daring telah membantu dalam hal menarik yang lebih menantang dari model pembelajaran tatap muka. Tak terbatas waktu dan tempat belajar memberikan peserta didik kebebasan untuk memilih saat yang tepat dalam pembelajaran berdasarkan kepentingan mereka, blended learning dapat membuat peserta didik lebih aktif dalam proses pembelajaran di kelas dan online.

2. E- learning/Daring

Rosenberg menyampaikan E-learning berbentuk pada penggunaan teknologi internet untuk memberikan serangkain solusi yang dapat meningkatkan pengethuan dan adanya keterampilan . bahkan ada yang menjalaskan bahwa e-learning digunakan sebagai segala teknologi yang digunakan untuk mendukung usaha-usaha pengajaran dengan teknologi elektronik internet. Syarat personal dalam pengajar dapat berinteraksi dengan baik layaknya seseorang guru berkomonikasi dengann murid didepan media teknologi. Hal membuat peserta didik betah berlama-lama di depan layar komputernya. Dengan itu membuat perbaikan pembelajaran dilakukan secepat mungkin oleh pengajar atau pengelola.

Karakter E-learning adalah :

- Menghasilkan jasa elektronik dimana guru dan siswa sesame dapat berkomunikasi dengan relative dan mudah dengan adanya batasan oleh hal protocol.

- Menggunakan bahan ajar bersifat mandiri dengan menyimpan tugas di computer sehingga akses guru dengan siswa kapan saja dimana saja dan bisa bersangkutan memerlukan sesuatu.

- Menggunakan waktu pembelajaran hasil perkembangan belajar dan hal yang berkaitan dengan administrasi dilihat dari kalian menggunakan computer setiap saat.

c. Tujuan penelitian

1. Mengetahui efektivitas daring berdasarkan pengalaman-pengalaman peserta didik.

2. Memberikan kelemahan dan kelebihan daring dalam pengalaman peserta didik

3. Mengingatkan apa suasana belajar daring dalam pengalaman peserta didik

4. Dan mengingat peserta didik dalam menghafal apa saja yang diperbuat dalam memperbaiki agar penerapan daring itu agar lebih menarik dan sempurna. 


\section{METODE/EKSPERIMEN}

Metode yang digunakan dalam kajian ini menggunakan berkomunikasi dengan subjek peneliti terkait pengalaman mereka tentang efektivitas daring dalam pembelajaran. Hasilnya 2 dari 5 responden merasakan menyatakan bahwa pembelajaran face to face itu lebih baik dan efektif, siswa merasakan bahwa mengaplikasikan pembelajaran daring untuk memperoleh berpusat pada pemberian tugas, selain itu bertanya juga tidak akan seluas dengan pembelajaran dengan saling tatap muka baik bertanya dengan guru maupun lainnya. Peneliti pun membaca semuanya mendalam dan menganalisis apa yang dibaca dari data itu semua sehingga sumber itu dapat dipercaya sehingga akan menjadi sebuah kesimpulan yang jelas dan padat.

1. Analisis data

\section{HASIL DAN PEMBAHASAN}

\section{a. Efektifitas daring berdasarkan kegiatan peserta didik sejak dini}

Peneliti hanya melakukan komunikasi kepada penelitian dengan pengalaman tentang efektivitas online belajar . hasilnya 2 dari 5 responden merasakan bahwa dengan pembelajaran ini sangat lebih efektif dan 3 responden lain menyatakan bahwa pemebelajaran face to face dirasa lebih efektif.

Mereka pun melakukan pembelajaran daring membuat semua hanya berpusat pada penugasan dan rasio pemberian materi sangatlah kecil. Selain itu juga komunikasi bertanya tidak senyaman pada saat tatap muka dengan guru maupun sekawan.

\section{b.Kelemahan dan kelebihan pembelajaran daring berdasarkan pengalaman peserta didik}

Kelebihan Pembelajaran daring :

1. Belajar lebih ringkas dan mudah mengaplikasikan pelajaran dengan mengikuti video tatap muka, para peserta didik sangat mempunyai kegiatan menjadi cepat untuk belajar ,sehingga siswa pun tidak perlu menghabiskan waktu untuk pergi ke sekolah.

2. Pendidikan Indonesia lebih sangat menonjol jika adanya sistem mengajar dan belajar seperti ini setidaknya siswa sebagai pendidikan Indonesia lebih maju walaupun hanya sedikit saja ,dengan menggunakan teknologi di Indonesia lebih bervariatif dengan adanya belajar online.

3. Peserta didik menghasilkan diri belajar dengan ini tidak akan memakan jadwal lebih dan dapat membuat pelajar bisa mengembangkan diri pada hal yang biasanya mereka lakukan sendiri. Dengan begitu siswa pun bukan hanya belajar tapi bisa mengembangkan bakar yang telah terpendam dalam diri nya yang mereka miliki.

Kekurangan Pembelajaran berbasis daring :

Tugas menumpuk walaupun mereka belajar di rumah tapi mereka pun. Tetapi merekapun Usahakankontenpadagambarjelas, danterlihatketika di baca. tidak akan merasakan tenang jika harus menjalani tugas yang sudah disampaikan oleh seorang guru dan guru pun hanya bisa menyampaikan tugas agar peserta didik bisa mendapatkan hasil yang terbaik.

2.Krisis kouta internet karena biasanya mereka hanya memakai sebulan sekali, kini mereka harus membeli paket dua sekali dalam sebulan saja. Dan walaupun mereka menggunakan WIFI tapi internet nya pun terbatas karena sudah ditentukan dalam pemakaian bila berlebihan pun WIFI menjadi bermasalah.

3.Konsep pembelajaran sulit di dapat, memang mungkin konsep pelajaran ini lebih menghemat waktu tapi tidak tentu materi pembelajaran yang mereka dapat lebih efektif. Karena banyak tugas yang mereka belum tentu tau konsep pembelajaran itu. 
c. Suasana pembelajaran daring berdasarkan kegiatan peserta didik

Pemateri memberikan pertanyaan mengenai pembelajaran daring dan mereka merasakan bahwa tidak menyenangkan seperti ada gangguan sinyal saat pembelajaran dimulai. Dan adapun yang mengatakan lebih efektif karena memberikan rasa bahwa belajar seperti ini bisa dilakukan.

d. Harapan peserta didik mengenai hal apa yang mereka harus lakukan dalam pembelajaran ini.

1.Penyampaian konsep belajar berharap agar guru tetap melakukan pembelajaran yang sudah ada. Siswa pun memberikan saran bahwa penjelasan materi lebih baik melakukan video atau foto sehingga mereka merasa materi itu lebih bisa di mengerti.

2.Melakukan memanfaatkan teknologi ini dengan sesuai apa yang siswa suka pada saat ini dengan sosial media mereka karena dengan begitu siswa akan mereka lebih semangat dan antusias dan merasakan jadi tidak bosan ,adapun siswa yang memberikan solusi dengan melakukan INSTAGRAM LIVE VIDEO karena mereka mampu melakukan dan merasakan kesenangan dan bisa ada nya pertanyaan yang disampaikan kepada yang lain.

1.

\section{PENUTUP}

Perkembangan aplikasi sangat menjadi sorotan yang menonjol besar dalam pendidikan , dan para pendidik memanfaatkan untuk mempercepat kegiatan belajar serta peningkatan kualitas dan kuantitas pendidikan , pandangan siswa terhadap pembelajaran daring ini membuat mereka merasa tidak efisien jika dalam praktik guru lebih melakukan penyampaian tentang tugas apa yang dilaksanakan bukan malah melakukan menyampaikan materi dahulu. Dan siswa merasa banyak hal yang mereka rasakan saat melakukan pembelajaran di rumah seperti tidak menyenangkan dan tidak bersemangat dan membuat pikiran menjadi terganggu karena tugas yang selalu menumpuk dalam setiap harinya.

Peserta didik merasakan mungkin kegiatan belajar dirumah itu lebih efektif dan menarik tetapi sebaliknya karena mereka merasakan setelah berbulan-bulan itu membuat nya sangat tidak nyaman. Dan siswa pun sangat berharap penerapan pembelajaran daring ini diperbaiki seperti hal nya yang sudah di rekomendasikan siswa sebelumnya dengan melakukan video atau foto dan melakukan kemsajuan teknologi yang lebih baik.

Solusi yang bisa saya berikan mengenai permasalahan ini adalah memberikan informasi di awal pembelajaran melakukan untuk kerjasama dengan antar kelas melalui komunikasi seperti akses whatshapp ,google meet untuk mengumpulkan data tugas yang ada.

\section{DAFTAR PUSTAKA}

Abidin, Z. (2020). efektivitas pembelajaran jarak jauh pada masa pandemi covid 19. journal.ippmunindra.ac.id.

Amalia, G. (2020). efektivitas model problem based learning berbasis daring terhadap hasil belajar IPA . Jurnal.unibrah.ac.id.

Daheri, M. (2020). efektivitas whatshapp sebagai belajar daring . jurnal pendidikan guru sekolah dasar, 706716.

Khusniyah, N. (2019). efektivitas pembelajaran berbasis daring sebuah bukti pada pembelajaran bahasa 
inggris. journal.uinmataram.ac.id, 19-33.

LD Pratama, W. I. (2020). efektivitas penggunaan media edutainment di tengah pandemi covid 19. aksioma:jurnal program 2020.fkip.ummetro.ac.id, 278-285.

Maulana, H. (2020). analisis tingkat stres mahasiswa terhadap pembelajaran daring pada mata kuliah statistik bisnis. jurnalnasional.ump.ac.id, 1050-1058.

Sadikin, A. (2020). pembelajaran daring di tengah wabah covid-19 . journal.unja.ac.id, 214-224.

Satrianingrum, A. (2020). persepsi guru dampak pandemi covid 19 terhadap pelaksanaan pembelajaran daring di PAUD. jurnal ilmiah pendidikan matematika, 2097-2103.

Schramm, J. (2018). improved student reasoning about carbon-tranforming process through inquiry based learning activities derived from an empirically validated learning. research in science education.

Wasito, D. (2017). efektivitas pembelajaran kooperatif(cooperative learning) untuk meningkatkan keterampilan sosial pada siswa taman kanak. journal school psychology , 120-133.

Abidin, Z. (2020). efektivitas pembelajaran jarak jauh pada masa pandemi covid 19. journal.ippmunindra.ac.id.

Amalia, G. (2020). efektivitas model problem based learning berbasis daring terhadap hasil belajar IPA . Jurnal.unibrah.ac.id.

Daheri, M. (2020). efektivitas whatshapp sebagai belajar daring . jurnal pendidikan guru sekolah dasar, 706716.

Khusniyah, N. (2019). efektivitas pembelajaran berbasis daring sebuah bukti pada pembelajaran bahasa inggris. journal.uinmataram.ac.id, 19-33.

LD Pratama, W. I. (2020). efektivitas penggunaan media edutainment di tengah pandemi covid 19. aksioma:jurnal program 2020.fkip.ummetro.ac.id, 278-285.

Maulana, H. (2020). analisis tingkat stres mahasiswa terhadap pembelajaran daring pada mata kuliah statistik bisnis. jurnalnasional.ump.ac.id, 1050-1058.

Sadikin, A. (2020). pembelajaran daring di tengah wabah covid-19 . journal.unja.ac.id, 214-224.

Satrianingrum, A. (2020). persepsi guru dampak pandemi covid 19 terhadap pelaksanaan pembelajaran daring di PAUD. jurnal ilmiah pendidikan matematika, 2097-2103.

Schramm, J. (2018). improved student reasoning about carbon-tranforming process through inquiry based learning activities derived from an empirically validated learning . research in science education.

Wasito, D. (2017). efektivitas pembelajaran kooperatif(cooperative learning) untuk meningkatkan keterampilan sosial pada siswa taman kanak. journal school psychology , 120-133.

Widayati, S. (2020). respon mahasiswa pada proses pembelajaram mata kuliah daring. journal.unnes.ac.id, 19-33. 
46 | Jemari: Jurnal Edukasi Madrasah Ibtidaiyah, Vol. 3 No. 1, Halaman: 41 - 46, January, 2021

Widiyono, A. (2020). efektivitas perkuliahan daring pada mahasiswa PGSD di saat pandemi covid 19. jurnal pendidikan.

Y.Thushima. (2009). erratum to: roles of attention in perceptual learning from perspectives of pyshopysics and animal learning.

Yunitasari, R. (2020). pengaruh pembelajaran daring terhadap minat belajar siswa pada masa covid 19. jurnal ilmu pendidikan , 30-38. 